\title{
The problem of dual citizenship for ethnic minorities in Central and Eastern Europe
}

UDC 327.58:342.718](4-11+4-191.2)

DOI https://doi.org/

10.24195/2414-9616-2019-2-90-94

Lutsyshyn Halyna Ivanivna

Doctor of Political Science,

Professor of the Department of Political

Science and International Relations,

L'viv Polytechnic National University

Metropolitan Andrey Str., 5, L'viv, Ukraine

Klymchuk Iryna Ihorivna

$\mathrm{PhD}$ in Political Science,

Assistant at the Department of Political

Science and International Relations,

L'viv Polytechnic National University

Metropolitan Andrey Str., 5, L'viv, Ukraine

\begin{abstract}
The article analyzes the issue of dual citizenship for ethnic minorities in Central and Eastern Europe. Today, many Central and Eastern European countries grant preferential access to citizenship on an ethnic basis, due to regional demographic indicators, in particular, decline in birth rates, high emigration and changes in the ethnic structure of modern states. On one side, the problem of dual citizenship is an important component of international and national law, on the other - it is an essential element of intergovernmental relations policy which affects national and international security.

Ethnic citizenship is viewed by many governments as an important factor in ethno-demographic consolidation, but it can also have unforeseen consequences when co-eternity is used by some individuals for personal gain (receiving benefits, welfare, etc.).

It is noted that ethnic groups form a significant part of the population of individual states which have a common history of border relations. The question of dual citizenship in Ukraine is especially relevant for ethnic Hungarians and Romanians in Zakarpattya, Bukovina, Odessa region and Russians in the Crimea. We came to the conclusion that many Ukrainians try to use this case as an additional occasion for work, study and freedom of movement. This situation has led to the spreading of the problem of hidden dual citizenship in certain Ukrainian regions - Crimea, Zakarpattya, Bukovina and destabilization in the socio-political sphere with the transition to threats of the territorial integrity of Ukraine. The study showed that in case of legalization of equivalent dual citizenship, its carriers face the regulations and requirements of two politico-legal systems which often contradict each other. It is stated that there are no generally accepted rules - each country has its own traditions, migration law, citizenship laws. The authors tried to point out both positive and negative sides of proliferation of dual citizenship, in particular, the intensification of interstate relations (Ukraine-Hungary, Hungary-Slovakia, Ukraine-Romania) and stress on controversial and ambiguous aspects of this problem. Key words: dual citizenship, national consolidation, national policy, ethno politics.
\end{abstract}

Introduction. Transboundary ethnic groups make up a significant part of the population of many Central and Eastern European countries, and therefore the issue of dual citizenship is relevant and important for modern Hungary, Romania, Slovakia, Serbia, Montenegro and Ukraine. Today, 17 EU states allow dual citizenship, one state (Slovakia) prohibits, 10 states allow in certain circumstances. Since 2010, some countries like Poland, Hungary, Bulgaria, Czech Republic, Latvia, etc. have provided certain advantages on the principle of ethnic origin (visa regime, employment, acquisition of citizenship, etc.) in laws of direct action, for example, "On Foreign Compatriot" (Poles, Slovaks, Czechs, Hungarians, etc.). In order to avoid additional difficulties with dual citizenship, states often have bilateral agreements where the conditions for dual citizenship are clearly prescribed, according to which citizens of dual citizenship in only one state (territory of actual residence) do military service, pay taxes and take part in elections.

The problem of dual citizenship is an important component of international and national law, an essential element of intergovernmental relations policy which affects national and international security. In case of legislative registration of an equivalent dual citizenship its carriers are facing regulations and requirements of two political legal systems which contradict each other. In particular, there are certain disagreements about tax legislation, electoral rights, military service, the right to education, health care, etc. As practice shows, this problem is relevant for Ukraine today.

The question of dual citizenship has recently been actively discussed by both representatives of the world community and Ukrainian politicians. This problem is dealt with by scientists of various fields - specialists in constitutional law, international law scholars, political scientists, historians, etc. There are no generally accepted rules on dual citizenship adoption - every country has its own traditions, migration law, citizenship laws; every state itself decides who can be considered as its citizen and who is not.

This issue is discussed in a number of works, in particular, in the works of the following foreign scientists: F. Berber, G. Ellinek, P. Weiss, X. Van Penhais, A. Makarova. Among Ukrainian researchers, special attention is paid to the works of such scientists as R. Bedryi, V. Evtukh, Y. Rymarenko, O. Kolomiets, V. Krischenko, A. Kolodiy, A. Kisse, O. Kartunov, etc.

Goal and tasks. The purpose of the article is analyzing the issue of dual citizenship for ethnic minorities in Central and Eastern Europe; studying positive and negative sides of proliferation of dual citizenship and threats, in particular, the intensification of interstate relations (Ukraine-Hungary, Hungary-Slovakia, Ukraine-Romania).

Research methods. Proceeding from the problems of the article, a comparative method is used in the study of traditions, migration law as well as European countries' treaties and laws on dual citizenship. 
A special attention is paid to empirical research methods: expert interviews, sociological surveys, studying and analyzing of documents, statistical data.

Results. The practice of application of dual citizenship in Ukraine has a long history, although Ukrainian Constitution establishes single citizenship. In Ukrainian Law "On Citizenship of Ukraine", passed in 2001, states that Ukrainian legislation on citizenship is based, in accordance with Art. 4 of the Constitution of Ukraine, on the principle of "single citizenship" [2]. In Ukraine, problems with dual citizenship, acquired by a person under certain conditions without personal appeal (automatically), and with responsibility for conscious concealment of dual citizenship, are not regulated.

The views of Ukrainian politicians on the problem of the spreading of dual citizenship are different - some consider it is a positive, modern phenomenon, others - oppose. For example, the leaders of the Opposition Block, in their public speeches, substantiated the advantages of dual citizenship for Ukraine, in particular, they pointed out that dual citizenship would give an opportunity to unite Ukrainians around the world and would contribute to strengthening the influence of Ukraine in the countries of the second citizenship and the success of the European integration process will positively influence the influx of labor resources into Ukraine and the engagement of economic opportunities of the countries of the Ukrainians second citizenship, will facilitate simplification of business for entrepreneurs, improve legal and social protection of Ukrainians abroad [6]. Plenty of Ukrainian politicians, in particular, representatives of the right-wing forces, declare that dual citizenship is a threat for Ukrainian national security, as in some Ukrainian regions, the fourth part of the population can be recognized as neighboring states citizens, and this has its political, legal, national, cultural, etc. consequences. Negative is the fact that dual citizenship significantly inhibits the process of formation of the common national values, nation development priorities and, accordingly, national consolidation of the society.

The question of dual citizenship in Ukraine is especially relevant for ethnic Hungarians and Romanians in Zakarpattya, Bukovina, Odessa region and Russians in the Crimea. European Convention on Nationality is an internationally-legal document adopted by the Council of Europe in Strasbourg in 1997 that regulates the conditions and procedures for the acquisition, loss and restoration of citizenship, the principles of action in case of continuity of States or multiple citizenship. Ukraine ratified the "European Convention on Nationality" in 2006, although it contradicts the Constitution of Ukraine [1].

As $\mathrm{O}$. Kolomiets emphasizes that the issue of dual citizenship the most often arises as a result of:

- birth of a child in a state where the principle of "soil rights" is in force; from parents who have citizenship of the state where the principle of "blood rights" applies (for example, Argentina - Russia, Brazil United Kingdom);

- in case of naturalization, if the legislation of the country, the citizenship of which an individual acquires, does not require refusal from the previous one (Spain - Russia, Israel - Ukraine);

- as a result of a woman married to a foreigner, if the legislation of the wife's country retains her citizenship, and the legislation of her husband's country gives her its citizenship [4, p. 296-301].

In order to avoid additional difficulties with dual citizenship, states quite often negotiate with each other about bilateral agreements that allow for the conditions under which citizens with dual citizenship in only one state (where they actually reside) do military service and pay taxes. It should be noted that most of the states unwillingly agree with dual citizenship of their citizens. For example, among CIS member-states only Turkmenistan in December 1993 negotiated for the conclusion of a treaty on dual citizenship with the Russian Federation. In nearly ten years, in April 2003, the Russian Federation and Turkmenistan decided to terminate the mentioned agreement.

As of today, insignificant part of the countries allows dual citizenship. In 2010, Romania, Bulgaria and Hungary adopted laws on granting dual citizenship to their compatriots living abroad. According to some sociological researches, every second Ukrainian takes a positive view about the idea of enacting the second citizenship [10]. For Ukrainian to have a Russian, Romanian, Polish or some other state passport is an additional opportunity for work, study and freedom of movement. For example, in Bulgaria with Ukrainian passport, students have to pay twice as much for education than Bulgarian citizens. In addition, in this country with Bulgarian passport, a person can apply for a job in a government agency, buy land, etc. In some countries, citizenship can be bought, for example, the citizenship of Dominica can be bought for 150 thousand dollars. It gives visa-free entry to hundreds of countries for a person with a passport of this country. Regarding phenomenon of hidden (potential) dual citizenship, this, beside legal, is primarily a moral-psychological and national-patriotic problem [7, p. 35].

The majority of the modern developed countries strictly regulate the procedure of acquiring citizenship, which is based on the strategy of preserving ethnocultural identity of the society and respecting the value of citizenship of own country. Ukrainian scientist V. Crisachenko analyzed the models of establishment dual citizenship on the examples of different states. For example, in the United States, applicants for US citizenship make an Oath of devotion, the basic positions of which are: knowledge of English (official language of the state), that is certified by the swearing the oath in this language; proclamation of devotion to the values of American society, at first, its political and 
legal foundations [5, p. 82]. The procedure for granting citizenship in Canada is quite rigid. Although this country accepts about 200,000 immigrants annually, but among other obligatory conditions (for example the absence of criminal liability), there is a requirement for knowledge of the language: English for Canada, and French for Quebec. In addition, immigrants who pretend for a citizenship must have a certain profession, level of education, etc. Similar rigid criteria and requirements are placed to the new citizens and other countries - Australia, New Zealand, etc.

A certain part of the countries actively supports the policy of the so-called primordia list approach - the common ethnic origin of the citizens from different countries and as a result granting of certain preferences and privileges by a specific state to their compatriots abroad (namely ethnic diaspora). Such a policy also includes the possibility of granting dual citizenship not only de facto, but also de jure. Germany is a good example, as all people with German ethnic origin are potentially considered as FRG citizens regardless of their county of residence. After the Second World War Germany began engaging actively in foreign labor (primarily from Turkey), giving migrants the right to permanent residence and preferential conditions for acquiring German citizenship.

Today, analysts emphasize significant changes in German national structure; in particular, they more often predict that from 2010 the correlation in the age group to forty years in the German society will change in favor of migrants and their descendants. Today, ethnic Germans are risking turning themselves into a minority on their own land. A similar tendency is observed in France, Great Britain, the Netherlands, Belgium and some other European countries. Israel is implementing similar policy, creating favorable conditions for returning the representatives from Jewish diaspora to their historic homeland, as all of them are considered as potential Israeli citizens. The principle of preservation of the national identity is a key in Israel, where the concepts of "ethnicity", "faith" and "state" are closely interconnected. According to various assessments, there are more than 50 thousand Ukrainian and Israeli passport owners in Israel [3].

The model of "dual citizenship" is also realized by some European countries, for example, Greece and Romania. Separate states as Poland, Slovakia, Hungary, Bulgaria, etc. give certain advantages by the principle of ethnic origin (visa regime, employment, acquisition of citizenship, etc.) in the laws of direct action, for example, "On Foreign Compatriot" (Poles, Slovaks, Czechs, Hungarians, etc.).

In Romania's legislation, Article 37 of its Citizenship Act it is stated that foreign citizens and stateless people, who were deprived of Romanian citizenship before December 22, 1989, for different reasons beyond their control, and their descendants, have a right to return Romanian citizenship. In fact, it is about that all residents of Chernivtsi region, whose parents or ancestors had Romanian passport before June 28, 1940, have a right to get Romanian citizenship [11]. So, thousands of Chernivtsi region residents received their pass to Schengen zone - which is a passport of neighboring Romania.

According to various calculations, only in Bukovina fifty thousand compatriots can be simultaneously Romanian citizens. A number of scientists emphasize certain threats to national security when one third of the population in a separate region receives passports of a neighboring state.

In 2011, in Slovakia, the Parliament prohibited dual citizenship; in particular, it was going on about ethnic Hungarians, who make about 10 percent of the population. Now, if a Slovak citizen has a passport of another country, he is automatically deprived of Slovak citizenship and pays a large fine. Today, Slovakia and Hungary are trying to improve relations and agreed to start the negotiations to resolve the controversial question. Although Romania was loudly outraging, when Hungary in the 1990s began to issue "Hungarian card" to ethnic Hungarians in Romania.

The negative aspect of dual citizenship can be the change of national identity or the promotion of dual national identity, as one of the main prerequisites is the proving of belonging to Romanian nationality, for example. The last few years the archives of Chernivtsi region have been really full of people: thousands of Ukrainians are trying to get documentary confirmation of their pedigree, in particular, to prove that their relatives once lived under the jurisdiction of Bucharest. There are dozens of companies in Chernivtsi, Lutsk, L'viv that, for a small fee, will change (diversify) the genealogy tree.

In Ukraine, until recently, on the Romanian Consulate website and the "Romanian Official Bulletin" the lists of Romanized Ukrainians were published, but subsequently such information was stopped to distribute because, in fact, the number of such people is rather large and all of them, according to Ukrainian legislation, are violators of the law.

There is a threat for Ukraine, if at least one fifth of the region's population receives foreign passports, more autonomies, except Crimean, can appear in Ukraine. For example, separate Romanian political forces have for a long time supported an idea of Greater Romania revival, including Bukovina and Bessarabia. Therefore, they distribute Romanian passports to their neighbors so actively. Although this trend is not new, since ancient times, both empires - Russian and Austrian - have been unceasingly recruiting scientists, officials and military officers from Ukraine.

In 2010, Hungarian parliament accepted a law on simplified procedure for acquiring Hungarian citizenship, but in practice this law came into effect on January 1,2011 . Subsequently, changes were made in 
Hungarian constitution which came into force at the beginning of 2012, namely, ethnic Hungarians or their descendants are given the right to acquire citizenship "by the right of blood" in different countries. Applications for acquiring Hungarian citizenship can be submitted by foreign citizens or their descendants who were Hungarian citizens before 1920 or in 1940-1945, speak Hungarian and do not make a threat to national security. Previously, the procedure lasted 1-1.5 years, since January 2011 - only three months [8].

At the beginning of 2011, the number of Hungarian from Ukraine acquiring second citizenship increased, in particular, at the Hungarian Consulate General's premise in Uzhgorod, those who wish take an oath of allegiance to the Republic of Hungary and receive a document about returning of Hungarian citizenship. "Document about the returning of Hungarian citizenship" is fastened by a signature of the Hungarian President and the seals of the Ministry of Foreign Affairs and the Ministry of Justice of the Republic of Hungary. The document also contains text of the oath, in which a person, who signed it, recognizes the Hungarian Republic as his/her homeland and swears to protect and serve it "depending on his or her strengths and abilities". In addition, the oath adoption by Zakarpattya for loyalty to Hungary can be a catalyst for the extreme right-wing forces of the region and induce them to take anti-Hungarian actions and reactions.

Recently, Hungarian Parliament adopted a law on establishing a separate Ministry for Foreign Affairs of the Hungarians. After all, foreign Hungarians with double Hungarian citizenship get all rights that Hungarian citizens also have and in this regard they will no longer fall within the scope of the Ministry of Foreign Affairs of Hungary. According to this law, it is planned to create constituencies outside of Hungary. It will give an opportunity for Zakarpattya Hungarians to become Hungarian Parliament deputies. There is no official reaction of the Ukrainian authorities on this political initiative of the neighboring state. The only reaction is public appeal by the head of the Zakarpattya regional organization of the Congress of Ukrainian Nationalists (OUN) Oleksandr Skachko [9]. He believes that ethnic Hungarians of Zakarpattya can be used for political purposes and suggests that several dozen thousands of Zakarpattya already had Hungarian passports. He suggests that such a trend is dangerous and the Security Service of Ukraine should be more interested in it. Alexander Skachko is sure that Ukraine must oppose the expansive policies of neighboring countries more decisively, in particular, Hungary about Zakarpattya.

As we see, in recent years, the strengthening of the negative foreign policy influence of the neighboring states on the Ukrainian constitution can be more actively observed. The situation, which has developed in Ukraine in recent years with the spreading of hidden dual citizenship shows that the socio-political situation in certain Ukrainian regions - Crimea, Zakarpattya, Bukovina has a tendency for increasing destabilization with the transition to threats of the territorial integrity of Ukraine.

The existing trends in the ethnic sphere and the attempts of other countries to use their problems in their own interests can cause ethno-national and inter-state conflict. Among the foreign policy factors, which have a negative impact on the Ukraine's national consolidation process, promote the "split of the nation", can be spreading of hidden dual citizenship, it contributes to the formation of a dual national identity, intensifies interethnic contradictions in certain Ukrainian regions, aggravates interstate relations.

Conclusions. Therefore, the study shows that in case of legalization of equivalent dual citizenship, its carriers face the regulations and requirements of two politico-legal systems which often contradict each other. There are certain inconsistencies regarding tax legislation, electoral rights, military service, etc. It should be noted that in the issue of dual citizenship there are no generally accepted rules - each country has its own traditions, migration law, citizenship laws.

The analysis showed that the outlined issues are rather complex and ambiguous in its solutions and require new approaches in the system of interstate, international relations and ethno-politics development in general. Many questions are unsettled and controversial, in particular, the role of national minorities and their ethnic homelands in the process of national consolidation, and the formation of political nation is significantly underestimated by the Ukrainian politician. Therefore, the search for scientifically substantiated components for the solution of this problem, the improvement of ethno-national policy stays relevant, timely and necessary both in view of science and wide public.

\section{LITERATURE:}

1. Європейська конвенція про громадянство. Страсбург, 6 листопада 1997 року. URL: http:// zakon.rada.gov.ua/cgi-bin/laws/main.cgi?nreg=994_004.

2. Про громадянство України : Закон України / Верховна Рада України. 2001. № 16. Ст. 5. Законодавство України. URL: https//zakon.rada.gov.ua/laws/ show/2235-14.

3. Клочко $€$. Подвійне громадянство: зручність чи злочин? BBC UKRAINIAN. URL: www.bbc.com/ukrainian/indepth/story/07/090701_ citizenship_ob.shtml.

4. Коломієць О. Інститут подвійного громадянства (біпатризму) у міжнародному праві: проблеми і перспективи. Наукові праці МАУП. 2010. Вип. 1 (24). C. 296-301.

5. Крисаченко В. Етнополітична стабільність України в міжнародному контексті. Стратегічна панорама. 2009. № 4. С. 82.

6. Подвійне громадянство: що підказує Україні європейський досвід. Європейська правда. URL: www.eurointegration.com.ua/experts/21/07/15/7052051. 
7. Тарасюк Г. Проблема реалізації принципу єдиного громадянства в Україні. Економіка. Фінанси. Право. 2009. № 8. С. 35.

8. Тужанський Д. 100 тисяч вірних Угорщині: історія та приховані деталі паспортного скандалу на Закарпатті. Європейська правда. URL: www.eurointegration.com.ua/articles/2018/09/20/7087153.

9. Україна-Угорщина: скільки коштує подвійне громадянство? ХВИЛЯ. URL: www.hvylya.net/ analytics/politics/ukrayina-ugorshina-skilki-koshtuepodvijne-gromadianstvo.html.

10. Яковлева Г. Друге чи подвійне громадянство? Hаше слово. URL: www.nasze-slovo.pl/druge-chipodvijne-gromadjanstvo.

11. Romanian Citizenship Law. Legislationline. URL: www.legislationline.org/.../action/.../Romania Citizenship la.

\section{REFERENCES:}

1. levropeiska konventsiia pro hromadianstvo. Strasburh, 6 lystopada 1997 roku. URL: http:// zakon.rada.gov.ua/cgi-bin/laws/main.cgi?nreg=994_004.

2. Zakon Ukrainy "Pro hromadianstvo Ukrainy" Verkhovnoi Rady Ukrainy, 2001, № 16, st. 5. URL: https//zakon.rada.gov.ua/laws/show/2235-14.

3. Klochko Ye. Podviine hromadianstvo: zruchnist chy zlochyn? BBC UKRAINIAN. URL: www.bbc.com/ukrainian/ indepth/story/07/090701_citizenship_ob.shtml.
4. Kolomiiets O. Instytut podviinoho hromadianstva (bipatryzmu) u mizhnarodnomu pravi: problemy i perspektyvy. Naukovi pratsi MAUP. 2010. Vyp. 1 (24). S. 296-301.

5. Krysachenko V. Etnopolitychna stabilnist Ukrainy v mizhnarodnomu konteksti // Stratehichna panorama. 2009. № 4. S. 82.

6. Podviine hromadianstvo: shcho pidkazuie Ukraini yevropeiskyi dosvid. Yevropeiska pravda. URL: www.eurointegration.com.ua/experts/21/07/15/7052051.

7. Tarasiuk H. Problema realizatsii pryntsypu yedynoho hromadianstva $v$ Ukaraini. Ekonomika. Finansy. Pravo. 2009. № 8. S. 35.

8. Tuzhanskyi D. 100 tysiach virnykh Uhorshchyni: istoriia ta prykhovani detali pasportnoho skandalu na Zakarpatti. Yevropeiska pravda. URL: www.eurointegration.com.ua/articles/2018/09/20/7087153.

9. Ukraina-Uhorshchyna: skilky koshtuie podviine hromadianstvo? KHVYLIA. URL: www.hvylya.net/analytics/politics/ukrayina-ugorshina-skilki-koshtue-podvijnegromadianstvo.html.

10. Yakovleva $H$. Druhe chy podviine hromadianstvo? Nashe slovo. URL: www.nasze-slovo.pl/drugechi-podvijne-gromadjanstvo.

11. Romanian Citizenship Law. Legislationline. URL: www.legislationline.org/.../action/.../Romania_Citizenship_la.

\section{Проблема подвійного громадянство для етнічних меншин в країнах Центральної та Східної Європи}

Луцишин Галина Іванівна

доктор політичних наук, профресор каседри політології та міжнародних відносин Національного університету «Львівська політехніка» вул. Митрополита Андрія, 5, Львів, Україна

\section{Климчук Ірина Ігорівна}

кандидат політичних наук асистент кафедри політології та міжнародних відносин Національного університету «Львівська політехніка» вул. Митрополита Андрія, 5, Львів, Україна
У статті проаналізовано питання подвійного громадянства для етнічних меншин в країнах Центральної та Східної Європи. Сьогодні багато країн Центральної та Східної Європи надають пільговий доступ до громадянства за етнічною ознакою, що пов'язане з регіональними демографрічними показниками, зокрема зниженням рівня народжуваності, високим рівнем еміграції та змінами в етнічній структурі сучасних держав.

3 одного боку, проблема подвійного громадянства є важливою складовою міжнародного та національного права, а з іншого боку, вона є важливим елементом політики міждержавних відносин, який впливає на національну та міжнародну безпеку. Етнічне громадянство розглядається багатьма урядами як важливий чинник етнічно-демограсрічної консолідації, однак може мати непередбачені наслідки, коли співетнічність використовується окремими особами для збагачення (отримання пільг, соціальних виплат тощо). Наголошується на тому, що етнічні групи складають значну частину населення окремих держав, які мають спільну історію прикордонних відносин. Питання подвійного громадянства в Україні є особливо актуальним для етнічних угорців та румунів у Закарпатті, Буковині, Одеській області та росіян у Криму. Ми дійшли висновку, що багато українців намагаються скористатися чією ситуацією як додатковою нагодою для працевлаштування, навчання та свободи пересування. Це привело до поширення проблеми прихованого подвійного громадянства в окремих регіонах України, а саме Криму, Закарпатті, Буковині, та дестабілізації соціально-політичної сфери, зокрема загрози територіальної цілісності нашої держави. Дослідження показало, що за легалізації еквівалентного подвійного громадянства його носії зіштовхуються з правилами та вимогами двох політико-правових систем держав, які часто суперечать одна одній. Зазначено, що не існує загальноприйнятих правил щодо вищезгаданої проблеми, адже кожна країна має свої традиції, закони про міграцію та громадянство. Автори намагалися вказати як на позитивні, так і на негативні сторони поширення подвійного громадянства, зокрема на загострення міждержавних відносин (Україна - Угорщина, Угорщина - Словаччина, Україна - Румунія), а також наголосити на спірних та неоднозначних аспектах чієї проблеми.

Ключові слова: подвійне громадянство, національна консолідація, політика нації, етнополітика. 